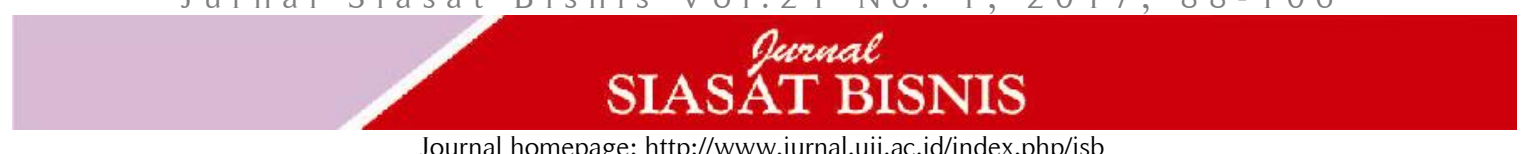

Journal homepage: http://www.jurnal.uii.ac.id/index.php/jsb

\title{
Analisis pengaruh trust dan risk dalam penerimaan teknologi dompet elektronik Go-Pay
}

\author{
Anjar Priyono \\ Fakultas Ekonomi Universitas Islam Indonesia, Yogyakarta, Indonesia \\ E-mail: anjarpriyono@gmail.com
}

\begin{abstract}
This study aims to examine the use of electronic payment using electornic wallet offered by Go-Jek. Dompet elektronik has been viewed as a new facility that facilitates customers to pay in an easy way. Nevertheless, many also view that the technology is risky, particularly those related to payment. Although contain risks for some people, other customers still trust the new technology and use it instead. Thus, this study considers both risk and trust to develop an integrative technology acceptance model. The empirical findings demonstrate that both risk and trust affect the acceptance of the electronic payment technology. Future research avenues are presented at the end of the paper.
\end{abstract}

Keywords: Technology acceptance model, trust, risk, mobile payment, PLS

\begin{abstract}
Abstrak
Penelitian ini bertujuan mengamati penggunakan pembayaran elektronik dengan menggunakan dompet elektronik (dompet elektronik) yang ditawarkan oleh Go-Jek. Dompet elektronik telah dipandang sebagai sebuah fasilitas yang memberikan kenyamanan dan kemudahan dalam bertransaksi. Namun demikian, banyak orang memandang bahwa teknologi ini juga memiliki risiko, terutama karena disebabkan terkait dengan pembayaran. Meskipun mengandung risiko menurut sebagaian orang, banyak pula pelanggan yang masih mempercainya dan tetap menggunakannya. Oleh karena itu, penelitian ini mempertimbangkan faktor risiko dan kepercayaan untuk mengembangkan Technology Acceptance Model yang komprehensif. Temuan empiris menunjukkan bahwa baik risiko maupun kepercayaan berpengaruh terhadap penerimaan teknologi pembayaran elektronik. Saran untuk penelitian lanjutan juga disajikan di akhir paper ini.
\end{abstract}

Kata kunci: Technology acceptance model, kepercayaan, risiko, pembayaran elektronik, PLS JEL:M11, M13, M15, M39 DOI: $10.20885 / \mathrm{jsb} . v 0121$.iss1.art6

\section{Later Belakang}

Tingkat penerimaan mobile payment mengalami peningkatan dari tahun ke tahun di berbagai negara (Flood et al. 2013). Di Amerika Latin, Kanada, Karibean, 31\% dari kartu bank dan $76 \%$ dari kasis dilengkapi dengan NFC yang memungkinan pelanggan untuk melakukan pembayaran dengan dompet elektronik (electronic wallet). Masing-masing negara menawarkan versi yang berbeda-beda dari dompet elektronik karena adanya kebutuhan untuk menghubungkan antara operator telepon seluler dan lembaga keuangan yang beroperasi di suatu negara. Sebagai misal, Google Wallet menjalin kemitraan dengan Sprint dan Citi MasterCard (Ross 2012) sementara itu Isis Mobile Wallet menjalin kerja sama dengan perusahaan wireless yaitu Verizon, T-Mobile dan AT\&T (Ross 2012). Kedua jasa dompet elektronik ini tidak tersedia di negara lain meskipun negara-negara yang berlokasi di tetangga USA. Jika di negara-negara sekitar USA saja dompet elektronik yang ditawarkan tidak tersedia, maka demikian pula halnya di Indonesia.

Di Indonesia memang tersedia perusahaan yang menawarkan jasa dompet elektronik akan tetapi penyedia jasanya adalah perusahaan lokal. Di Indonesia, salah satu perusahaan yang menawarkan dompet elektronik adalah Go-Pay. Go-pay itu sendiri adalah salah satu layanan yang ditawarkan oleh perusahaan induknya yaitu Go-Jek. Go-jek mengawali bisnisnya dari jasa 
transportasi taksi sepeda motor yang kemudian memperluas jaringan bisnisnya dengan menawarkan berbagai layanan. Dari berbagai layanan yang ditawarkan, Go-Pay adalah salah satunya. Layanan lain yang ditawarkan adalah Go-Shopping, Go-Salon, Go-Massage, Go-Box dan lainnya.

Go-Pay bekerja sama dengan beberapa bank terkemuka di Indonesia diantaranya Bank Mandiri, Bank BNI 46, Bank Central Asia dan beberapa bank lainnya yang memiliki dukungan teknologi. Selama ini, layanan yang ditawarkan oleh Go-Jek telah banyak diberitakan di media mendulang sukses besar. Bahkan, karena begitu suksesnya, layanan Go-Jek dituduh merusak persaingan yang sehat jasa transportasi taksi. Berdasarkan kesuksesan tersebut, layanan Go-Pay berupaya untuk mengikutinya dengan mengandalkan pada nama besar perusahaan induknya.

Nama besar perusahaan Go-Jek berpengaruh pada tingkat keterkenalan layanan yang ditawarkan oleh perusahaan tersebut. Dengan kata lain, nama besar Go-Jek memberikan kontribusi terhadap familiaritas (familiarity) layanan yang ditawarkan oleh perusahaan tersebut. Dalam beberapa literatur, disebutkan bahwa familiaritas suatu penyedia produk atau layanan akan meningkatkan kepercayaan terhadap penyedia produk atau jasa tersebut (Wang \& Benbasat 2005). Namun demikian, pengaruhi ini belum pernah diuji dalam konteks layanan dompet elektronik di Indonesia.

Faktor lain yang turut berperan dalam pengadopsian suatu teknologi adalah risiko (Pavlou 2003). Go-Jek sebagai perusahaan yang menyediakan layanan dompet elektronik diisukan mengalami masalah dalam hal legalitas. Pemberitaan di media massa menyoroti bahwa Go-Jek selama beroperasional belum memenuhi peraturan pemerintah terutama terkait perijinan (Anonim 2006).

Selain itu, para pengemudi armada Go-Jek juga tidak terdaftar secara resmi sebagai karyawan Go-Jek karena armada yang digunakan oleh para pengemudi tersebut statusnya dimiliki oleh pengemudi, bukan dimiliki oleh perusahaan. Selain isu legalitas kepemilikan armada tersebut, pengemudi Go-Jek dan pendapatan perusahaan juga tidak dikenakan pajak (Anonim 2006).

Risiko lain yang berpotensi muncul adalah risiko teknologi (Ackermann et al. 2011). Dompet elektronik termasuk teknologi yang belum banyak digunakan meskipun pengguna telah cukup mengenal berbagai macam metode pembayaran elektronik. Terlebih lagi, berdasarkan kajian pustaka yang dilakukan oleh peneliti, belum ada satupun penelitian yang membahas tingkat penerimaan Go-Pay oleh pelanggan di Indonesia. Penelitian dengan konteks lokal di Indonesia ini penting mengingat produk yang ditawarkan oleh layanan sejenis di tiap negara diorganisir oleh perusahaan yang berbeda.

Selain itu, perilaku pelanggan di masing-masing negara juga memiliki perbedaan karena adanya perbedaan budaya. Di beberapa negara tertentu, seperti misalnya USA, mereka lebih berani mengambil risiko atau risk takers. Sementara itu, di negara-negara Asia, seperti misalnya Indonesia, China, Malaysia, Singapura, dan Thailand, perilaku konsumen cenderung menganut risk averse atau menghindari risiko (Hoftstede 1988).

Berdasarkan uraian di atas, maka perlu dipertimbangkan beberapa faktor dalam analisis penggunaan teknologi dompet elektronik, yaitu risiko, familiaritas, dan kepercayaan. Technology acceptance model (TAM) adalah model yang paling banyak digunakan untuk menilai apakah suatu teknologi dapat diterima oleh pengguna (Pavlou 2003; Venkatesh \& Bala 2008). Model ini telah terbukti banyak digunakan untuk menilai apakah difusi inovasi teknologi dapat diterima pengguna atau tidak. Misalnya Jarvenpaa et al. (2000) menggunakan TAM untuk menganalisis tingkat penerimaan internet store oleh para pelanggan. Vander et al. (2003) juga mengintegrasikan niatan untuk membeli secara on-line ke dalam model TAM. Sementara itu, Vance et al. (2008) menggunakan TAM untuk menganalisis tingkat penerimaan teknologi secara lintas budaya. Dengan menggunakan model dasar TAM, penelitian ini akan memasukkan variabel-variabel baru yaitu risiko, familiaritas dan kepercayaan.

Penelitian ini bertujuan untuk menganalisis difusi teknologi dompet elektronik yang diperkenalkan oleh Go-Pay. Difusi teknologi Go-Pay ini tidak hanya memberikan manfaat terhadap perusahaan tersebut, tetapi juga perusahaan-perusahaan perbankan yang menjadi mitra. Analisis 
dalam penelitian ini akan dimulai dengan menggunakan model dasar technology acceptance model (Davis 1989). Model tersebut menyatakan bahwa Perceived Ease of Use (PEOU) dan Perceived usefulness (PU) adalah faktor-faktor utama yang mempengaruhi niat untuk menggunakan teknologi. Sebagai landasan teori, penelitian-penelitian sebelumnya dalam topik yang relevan dengan rumusan masalah yang diajukan di penelitian ini, terutama yang menggunakan TAM, akan dikaji. Dari hasil kajian tersebut, kemudian akan dirumuskan model.

Berdasarkan uraian di atas, maka dirumuskan pertanyaan penelitian sebagai berikut:

1. Apakah perceived usefulness berpengaruh positif terhadap intended use penggunakan aplikasi dompet elektronik?

2. Apakah perceived ease of usefulness (PEOU) berpengaruh positif terhadap intended use aplikasi dompet elektronik?

3. Apakah PEOU berpengaruh positif terhadap PU aplikasi dompet elektronik?

4. Apakah perceived risk (RSK) berpengaruh negatif terhadap intention to use aplikasi taksi online?

5. Apakah kepercayaan (trust) berpengaruh negatif terhadap persepsi risiko (perceived risk)?

6. Apakah kepercayaan berpengaruh negatif terhadap risiko untuk menggunakan aplikasi dompet elektronik?

7. Apakah kepercayaan berpengaruh positif terhadap perceived usefulness?

8. Apakah PEOU berpengaruh positif terhadap trust?

9. Apakah kepuasan (satisfaction) (SAT) terhadap aplikasi booking on line berpengaruh terhadap trust?

10. Apakah reputasi dari aplikasi dompet elektronik berpengaruh positif terhadap kepercayaan?

11. Apakah familiarity (FAM) dengan teknologi booking on line berpengaruh positif terhadap trust?

12. Apakah familiarity dengan teknologi dompet elektronik berpengaruh positif terhadap PEOU?

\section{Kajian Teori dan Literatur}

\section{Technology Acceptance Model(TAM)}

TAM dikembangkan dari Theory of Reasoned Action (TRA) yang dikemukakan oleh Fishbein dan Ajzen (1975). TAM seringkali disebut sebagai salah satu teori yang paling kokoh dalam bidang sistem informasi manajemen (Benbasat \& Barki 2007). Hasil penelitian yang menggunakan TAM menunjukkan bahwa model TAM cukup kokoh dan praktis untuk menjelaskan tingkat penerimaan teknologi oleh pengguna, terutama dalam konteks teknologi informasi (Pavlou 2003). Meskipun TAM awalnya dikembangkan untuk memprediksi perilaku individu untuk mengadopsi dan menggunakan teknologi informasi terbaru yang dikenalkan oleh pabrikan (Davis 1989), TAM telah banyak dikembangkan untuk memasukkan konstruk-konstruk yang sebelumnya tidak ada di model yang asli.

Beberapa penelitian yang melakukan hal tersebut diantaranya adalah Venkatesh dan Davis (2000) yang kemudian menyebut modelnya dengan TAM2, Venkatesh dan Bala (2008) menyempurnakan setelahnya dan memberi label untuk modelnya dengan nama TAM3. Penelitian lain memasukkan konstruk baru yaitu unsur kepuasan pengguna teknologi ke dalam model TAM. Hal tersebut dilakukan oleh Wixom dan Todd (2005).

TAM telah banyak digunakan dalam konteks pekerjaan maupun penelitian yang tidak terkait dengan organisasi (Gefen et al. 2003) dan secara konsisten menyebutkan bahwa sekitar 40\% dari varians niat individu dalam menggunakan teknonologi informasi sangat dipengaruhi oleh konteks dan asal negara (Gefen et al. 2003; Venkatesh \& Bala 2008).

TAM telah digunakan untuk penelitian teknologi informasi dalam berbagai konteks. Selain itu hubungan konstruk-konstruk yang ada di TAM telah seringkali terbukti nyata secara siginifikan 
tetapi masih belum terbukti dan berpotensi untuk memunculkan perdebatan untuk diterapkan dalam konteks teknologi informasi untuk booking alat transportasi on-line.

Dengan berdasarkan pada temuan-temuan penelitian sebelumnya, maka terdapat celah penelitian (research gap) untuk melakukan penelitian guna mengidentifikasi konstruk-kontruk kunci yang menjadi pendorong diadopsinya aplikasi dompet elektronik untuk sarana transportasi.

\section{Perceived usefulness (PU) dan Perceived Ease of Use (PEOU)}

Dengan memasukkan adanya konstruk kepercayaan (trust) dan risiko (risk) maka akan memperluas teori TAM yang ada (theory extension) sehingga memberikan pemahaman yang lebih luas. Tahapan berikutnya, di bab ini akan dibahas bagaimana perumusan hipotesis dan model dalam penelitian ini dikembangkan.

Berdasarkan TAM, pengguna teknologi informasi bertindak rasional ketika mereka memutuskan untuk menggunakan teknologi tersebut. Dengan berlandaskan pada premis ini, intention to use (USE) (niatan untuk menggunakan) sebuah teknologi yang baru ditentukan oleh perceived usefulness (PU) (persepsi kegunaan) dari menggunakan teknologi informasi dan juga perceived ease of use (PEOU) (persepsi kemudahan) untuk menggunakan dari teknologi informasi yang baru tersebut. Dalam penelitian ini, perceived usefulness menunjukkan penilaian subyektif dari kegunaan yang ditawarkan oleh aplikasi dompet elektronik untuk mempermudah mendapatkan jasa yang diinginkannya (Gefen et al. 2003). Sementara itu, PEOU menunjukkan seberapa jauh seorang pengguna teknologi aplikasi online berpandangan bahwa teknologi tersebut tidak banyak memerlukan upaya yang rumit (Davis 1989).

Berdasarkan uraian ini, maka dapat dirumumuskan bahwa semakin mudah teknologi aplikasi dompet elektronik untuk digunakan, maka semakin besar kemungkinan teknologi tersebut untuk dapat diterima oleh calon pengguna. Secara detail, rumusan hipotesis yang diajukan adalah sebagai berikut:

H1. PU berpengaruh positif terhadap intended use penggunakan aplikasi dompet elektronik

H2. PEOU berpengaruh positif terhadap intended use aplikasi dompet elektronik

H3. PEOU berpengaruh positif terhadap PU aplikasi dompet elektronik

Ketika mengadopsi teknologi aplikasi dompet elektronik untuk taksi, terdapat sejumlah risiko dan ketidakpastian yang muncul (Ackermann et al. 2011; Ion et al. 2011). Berdasarkan pada penelitian yang ada saat ini, terdapat dua bentuk ketidakpastian yang dapat muncul dalam adopsi teknolgo baru: ketidakpastian lingkungan (environmental uncertainty) dan ketidakpastian perilaku (behavioural uncertainty) (Pavlou 2003). Ketidakpastian lingkungan berasal dari jaringan komunikasi teknologi informasi yang berada di luar kendali pengguna. Bahkan, operator teknologi informasipun juga sulit untuk mengendalikan.

Risiko lain adalah munculnya harga yang lebih tinggi dari yang seharusnya. Hal ini terjadi karena aplikasi dompet elektronik langsung mencari jalur untuk menuju lokasi tujuan dari lokasi penjemputan. Dalam pemilihan jalur, aplikasi dompet elektronik tidak menampilkan jalur yang terpendek, tetapi jalur lain yang lebih panjang sehingga pelanggan harus membayar tarif yang lebih tinggi dari yang diharapkan.

Karena risiko yang berasal dari eksternal tersebut sulit untuk dikuantifikasikan, maka relatif sulit untuk mengukur obyektifitasnya. Dengan alasan ini, penelitian-penelitian sebelumnya telah memfokuskan pada makna dari perceived risk (Jarvenpaa et al. 2000; Vander et al. 2003). Konsisten dengan perspektif ini, penelitian ini mendefinisikan perceived risk sebagai kepercayaan subyektif dari pengguna bahwa terdapat kemungkinan terjadinya risiko untuk mengalami kerugian ketika menggunakan layanan aplikasi dompet elektronik (Pavlou 2003).

Definisi tersebut mencakup dua dimensi pokok yaitu ketidakpastian lingkungan dan perilaku, yang kemudian memiliki konsekuensi bahwa definisi tersebut mencerminkan perilaku oportunis dari penyedia jasa. Dengan menggunakan dasar hasil temuan dari hasil penelitian- 
penelitian sebelumnya (Benlian \& Hess 2011; Jarvenpaa et al. 2000; Pavlou \& Gefen 2004; Warkentin et al. 2002) yang menemukan perceived risk berpengaruh negatif terhadap niatan menggunakan teknologi informasi, maka dirumuskan hipotesis sebagai berikut:

H4. Perceived risk (RSK) berpengaruh negatif terhadap intention to use aplikasi taksi online.

\section{Trust (Kepercayaan)}

Secara umum, para peneliti dari berbagai disiplin ilmu sepakat adanya saling keterkaitan antara kesempatan, ketidakpastian dan kemungkinan adanya meraih manfaat (Mayer et al. 1995; Komiak \& Benbasat 2006). Dalam kondisi yang terdapat unsur ketidakpastian, secara otomatis mengandung risiko; dalam kondisi yang berisiko, diperlukan adanya kepercayaan agar pihak yang terlibat bersedia untuk mengambil tindakan (Mayer et al. 1995). Kepercayaan telah didefisikan dengan berbagai perspektif dan salah satu yang sering digunakan adalah yang diajukan oleh Mayer et al. (1995) yang secara harfiah mendefinisikan kepercayaan sebagai 'kebersediaan untuk menjadi tidak pasti sebagai akibat dari penyerahan terhadap pihak lain'. Berdasarkan definisi ini, kepercayaan merujuk pada suatu konsep yang terdiri dari tiga karakterer, yaitu: kemampuan, 'beneveolence', dan integritas (Jarvenpaa et al. 2000).

Secara karakteristik, ketiga karakteristik tersebut juga disebut sebagai 'trustworthiness' (Jarvenpaa et al. 2000). Konsisten dengan konsep kepercayaan dan penelitian yang mengamati konsep kepercayaan dalam hubungan penjual dan pembeli dalam lingkup on-line, penelitian ini mendefinisikan kepercayaan seperti pada penelitian Pavlou et al. (2007) dan Rousseau et al. (1998) sebagai keinginan pengguna untuk menerima ketidakpastian berdasarkan pada keyakinannya bahwa produk refurbish akan mampu memenuhi keinginannya. Dengan demikian, kepercayaan lebih mencerminkan persepsi tentang apa yang diharapkan dari pada apa yang ditakuti (McAllister 1995).

Penelitian-penelitian sebelumnya secara konsisten menunjukkan bahwa kepercayaan menunjukkan pengaruh positif terhadap minat mengadopsi (Kim et al. 2009; Komiak \& Benbasat 2006; McKnight et al. 1998; Wang \& Benbasat 2005).

Berdasar uraian di atas, maka dapat diprediksikan bahwa kepercayaan membantu pengguna untuk mengatasi kekhawatiran yang dihadapinya dan mendorong mereka untuk mengadopsi produk refurbish. Kepercayaan yang dimilikinya mampu mengatasi adanya persepsi yang muncul. Meskipun mereka percaya akan adanya risiko, akan tetapi adanya kepercayaan tetap mendorong mereka untuk mengadopsi teknologi booking on line. Dari uraian di atas, maka dapat dirumuskan hipotesis sebagai berikut:

H5. Kepercayaan berpengaruh negatif terhadap presepsi risiko

H6. Kepercayaan berpengaruh negatif terhadap risiko untuk menggunakan aplikasi dompet elektronik

H7. Kepercayaan berpengaruh positif terhadap perceived usefulness

\section{Perceived Ease of Use(PEOU)}

Dalam model TAM yang menggunakan trust sebagai salah satu variabelnya, Gefen et al. (2003) menyatakan bahwa PEOU berpengaruh terhadap trust. Penelitian dalam bidang electronic commerce yang ada mendukung pertanyaan tersebut dengan berargumentasi bahwa ketika berinteraksi dengan pihak lain, orang secara sadar menggunakan informasi yang ada seperti misalnya penampilan untuk menilai seberapa dapat dipercaya penyedia jasa atau produk (Gefen et al. 2003; Pavlou 2003; Vance et al. 2008; Wang \& Benbasat 2005). Gefen et al. (2003) berargumen jika pengembang website berupaya agar website yang dikelolanya menjadi lebih mudah digunakan dengan navigasi yang lebih mudah dipahami pengguna, maka dapat diartikan bahwa pengelola website mempunyai komitmen untuk menjaga hubungan dengan pelanggan. Argumen sejenis juga berlaku untuk pengelola booking on line. Jika pengelola booking on line menginvestasikan sejumlah sumber daya untuk mempermudah pengguna, maka dapat diartikan bahwa pengelola memiliki komitmen 
dan kesungguhan. Komitmen dan kesungguhan ini memberi keyakinan pada pelanggan bahwa mereka memang benar-benar tulus melakukan bisnis tanpa ada maksud berperilaku oportunis. H8. PEOU berpengaruh positif terhadap trust

\section{Satisfaction (Kepuasan)}

Telah banyak penelitian dalam bidang sistem informasi yang berhasil mengidentifikasi faktor-faktor yang mempengaruhi trust. Dengan pertimbangan untuk mencapai kesederhanaan, dalam penelitian ini hanya difokuskan tiga variabel, yaitu kepuasan, reputasi dan familiarity. Pemilihan faktor-faktor yang hanya terbatas pada ketiga faktor tersebut berdasarkan pada pertimbangan tingkat relevansi dengan obyek yang sedang diteliti.

Kepuasan telah banyak disebutkan sebagai penyebab utama terjadinya customer retention (Chiou \& Droge 2006). Kepuasan merupakan fungsi dari apa yang mereka harapkan (expected performance) dari suatu produk atau jasa dibandingkan dengan apa yang sebenarnya mereka terima (perceived performance). Kepuasan ini ditentukan oleh seberapa besar harapan yang diinginkan oleh pelanggan dapat dicapai oleh pelanggan.

H9. Kepuasan (SAT) terhadap aplikasi booking on line berpengaruh terhadap trust

\section{Reputation (Reputasi)}

Reputasi (reputation) menunjukkan efek positif terhadap kepercayaan dalam konteks tolo on line (Jarvenpaaetal., 2000; Kim et al., 2004). Alasan dibalik fenomena seperti ini adalah bahwa biaya yang akibatkan oleh perilaku tidak dapat dipercaya jauh lebih tinggi dibandingkan yang sudah mendapatkan kepercayaan. Karenanya, kepercayaan dapat dipandang sebagai sebuah aset yang memerlukan upaya untuk mencapainya.

Dari sudut pandang perusahaan yang memperoleh kepercayaan, mereka berupaya untuk menjaga kepercayaan yang telah diperoleh ini dengan tidak berperilaku oportunis. Jika mereka berperilaku oportunis, mereka dapat memperoleh keuntungan besar dalam jangka pendek tetapi harus mengorbankan keuntungan jangka panjang.

Penelitian ini menggunakan definisi reputasi seperti yang dikemukakan oleh Doney dan Cannon (1997) yang mendefinisikan sejauh mana pelanggan bersedia memberikan kepercayaan terhadap penyedia jasa, sehingga rumusan hipotesinya adalah sebagai berikut.

H10. Reputasi dari aplikasi dompet elektronik berpengaruh positif terhadap kepercayaan

\section{Familiarity (Familiaritas)}

Familiarity dengan teknologi telah banyak dikenal sebagai salah satu prasyarat trust dan sekaligus mampu mempengaruhi trust. Bukti akan hal ini banyak ditemukan di penelitian-penelitian sebelumnya, diantaranya Komiak dan Benbasat (2006), Gefen et al. (2003), Bhattacherjee (2002). Familiarity dapat diartikan sebagai pemahaman suatu entitas terhadap suatu obyek berdasarkan pada pengalaman berinteraksi di masa lalu. Familiarity dapat pula diartikan sebagai 'apa, siapa, bagaimana, dan kapan suatu fenomena terjadi'(Gefen et al. 2003).

Berdasarkan definisi tersebut, familiarity mencerminkan pemahaman terhadap tindakan pihak lain yang dilakukan saat ini, sedangkan trust berhubungan dengan keyakinan (belief) tentang tindakan di masa depan yang dilakukan oleh pihak lain (Gefen 2000). Dalam konteks penelitian ini, familiarity menujukkan seberapa besar pengguna teknologi booking on line memahami tata cara teknis untuk melakukan booking (cf. Gefen et al. 2003).

Menurut Gefen et al. (2003), familiarity menciptakan kepercayaan (trust) dengan meminimalkan kekuatiran seseorang terhadap pihak lain berdasar pengalaman masa lalu dimana pihak lain tersebut sebenarnya mempunyai kesempatan untuk melakukan tindakan oportunis tetapi tetapi hal itu tidak dilakukannya. Asumsi ini berlaku juga untuk penelitian ini. Jika pengguna teknologi aplikasi booking on line tidak merasa adanya indikasi perilaku oportunis dari penyedia 
jasa berdasar pengalaman menggunakan teknologi ini di masa lalu, maka kepercayaan pengguna akan meningkat (H11).

Dampak lain dari familiarity ada kaitannya dengan perceived ease of use. Penelitian sebelumnya menunjukkan bahwa peningkatan familiarity menyebabkan pengguna teknologi semakin mudah untuk menggunakan teknologi karena telah memahami prosedur dan fungsi-fungsi fitur dalam teknolgi tersebut (Cho et al. 2007; Gefen et al. 2003). Dari uraian ini, maka dirumuskan hipotesis sebagai berikut:

H11. Familiarity (FAM) dengan teknologi booking on line berpengaruh positif terhadap trust

H12. Familiarity dengan teknologi dompet elektronik berpengaruh positif terhadap PEOU

\section{Metode Penelitian}

\section{Populasi dan Sampel Penelitian}

Populasi penelitian ini meliputi seluruh pengguna aplikasi dompet elektronik yang ditawarkan oleh Go-Jek. Unit analisis penelitian ini adalah individu yang pernah melakukan aplikasi dompet elektronik yang dipilieh dengan menggunakan teknik convenience randomsampling. Dalam metode pemilihan sampel seperti ini, sampel dipilih berdasarkan kemudahan peneliti untuk menjangkau subyek yang dipilih untuk diikutkan dalam penelitian.

Data dikumpulkan dengan menggunakan survey langsung dengan kepada responden dengan mengguunakan kuesioner yang dicetak dengan harapan memberikan kesempatan kepada responden untuk melakukan klarifikasi jika ternyata terdapat item-item pertanyaan yang kurang jelas.

\section{Pengembangan instrumen}

Untuk mengembangkan instrumen yang sesuai dengan tujuan penelitian ini, maka dilakkan serangkaian strategi. Pertama, peneliti mengalisis penelitian-penelitian yang relevan di bidang ini. Beberapa kata kunci dimasukkan ke basis data Proquest, ScienceDirect dan Ebsco dengan menggunakan kata kunci TAM, dompet elektronik, dan booking application. Jika memungkinkan, item-item yang digunakan untuk pengukuran diadopsi dari skala yang telah ada dan kemudian dimodifikasi agar sesuai dengan konteks. Keseluruhan konstruk dalam model ini dioperasionalisasikan sehingga merefleksikan konstruk yang bermaksud untuk diukur dengan menggunakan skala Likert 5 poin.

Sebelum digunakan untuk mengumpulkan data dan disebar kepada para responden, instrumen penelitian ini diujikan melalui pilot test sejumlah 20 subyek. Dari hasil komentar dari para responden, hanya diperlukan sedikit revisi dan kemudian digunakan untuk mengumpulkan data di nara sumber yang sesungguhnya (MacKenzie et al. 2011).

Mengikuti saran dari Sekaran dan Bougie (2013), pertanyaan yang diajukan dalam kuesioner disusun dari yang paling umum kemudian menuju ke yang bersifat spesifik. Demikian pula dari sisi kesulitan kelompok pertanyaan disusun dari yang paling mudah dipahami ke yang paling sulit dipahami. Pengurutan tersebut berdasarkan pada kelompok konstruk. Sedangkan itemitem dalam masing-masing konstruk disusun secara random dengan maksud agar tidak dapat diidentifikasi maksud tertentu dari peneliti yang dikenali oleh subyek (Straub et al. 2004).

\section{Definsi Operasional dan Pengukuran Variabel Penelitian}

Penelitian ini menggunakan model dasar TAM dengan memasukkan beberapa variabel laten baru yang relevan dengan konteks penelitian. Beberapa variabel tersebut adalah risiko, familiarity, dan trust. Ketiga variabel laten tersebut diitegrasikan dengan model penelitian yang original sehingga menghasilkan model penelitian seperti grafik yang disajikan dalam Gambar 1. Definisi operasional, pengukuran masing-masing variabel, dan referensi yang dijadikan acuan untuk pengukuran variabel dijelaskan seperti tampak pada Tabel 1. 


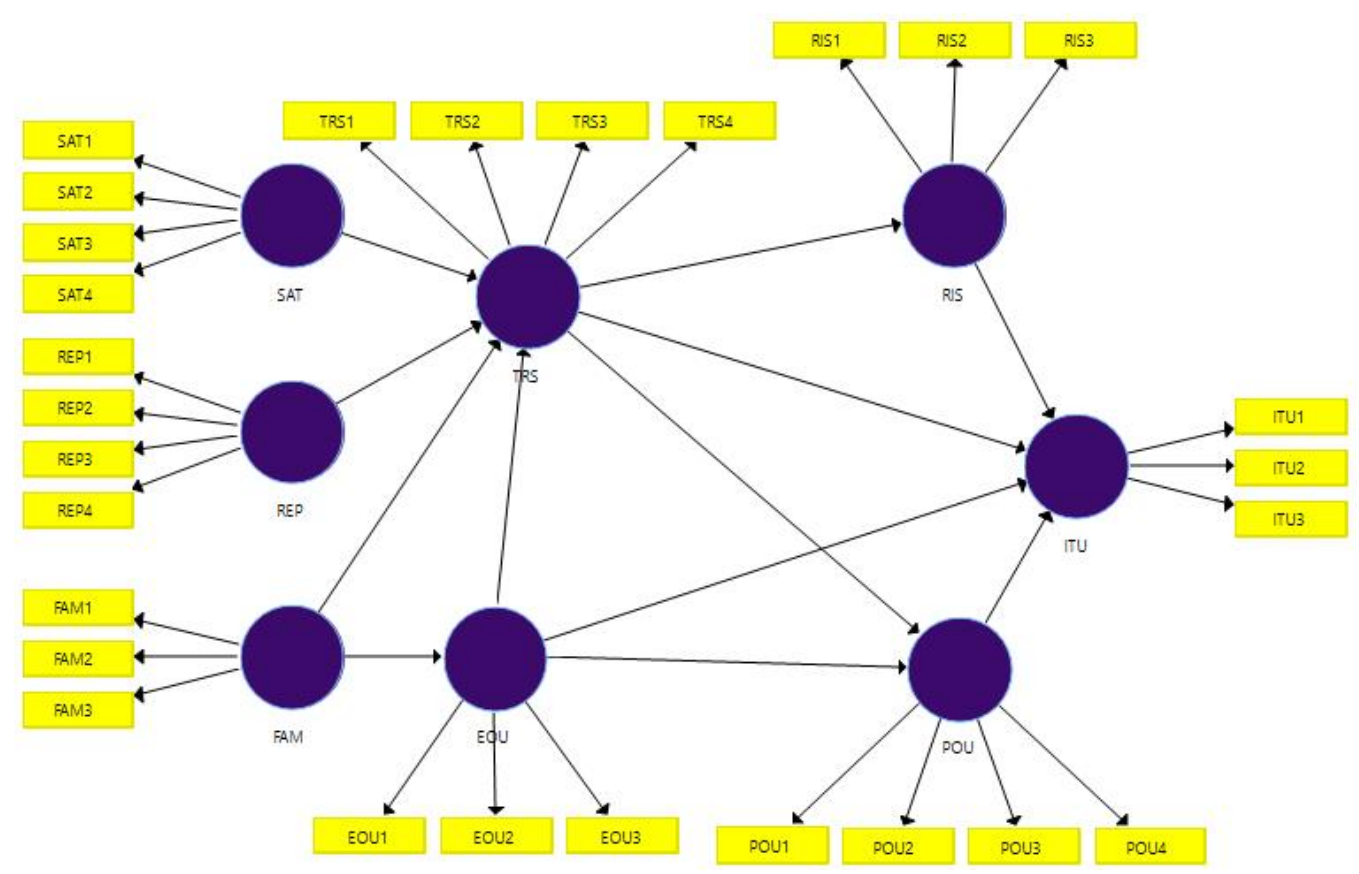

Gambar 1. Model Penelitian

Tabel 1. Definisi operasional variabel

\begin{tabular}{|c|c|}
\hline No. & Laten variabel \\
\hline 1. & $\begin{array}{l}\text { Intention to use } \\
\text { (Gefen et al. 2003) }\end{array}$ \\
\hline 2. & $\begin{array}{l}\text { Ease of use } \\
\text { (Wixom \& Todd } \\
\text { 2005) }\end{array}$ \\
\hline 3. & $\begin{array}{l}\text { Usefulness (Davis, } \\
\text { 1989; Gefen et al. } \\
\text { 2003) }\end{array}$ \\
\hline
\end{tabular}

4. $\quad$ Risk (Pavlou \& Gefen 2004)

Indikator/item pertanyaan

Saya akan menggunakan go payuntuk melakukan pembayaran transaksi pribadi saya

Saya sangat mungkin untuk menggunakan go payuntuk melakukan pembayaran transaksi pribadi

Saya bermaksud menggunakan go pay untuk kepentingan pembayaran transaksi pribadi di masa depan

Menurut saya go pay mudah untuk digunakan

Menurut saya mudah untuk menggunakan go pay seperti apa yang saya inginkan Menurut saya mudah untuk memahami bagaimana menggunakan go pay

Go pay memungkinkan saya untuk melakukan pembayaran transaksi pribadi saya

Go pay meningkatkan keefektifan saya dalam pembayaran transaksi pribadi

Secara keseluruhan, saya merasa go pay bermanfaat dalam pembayaran transaksi pribadi

Terdapat risiko potensional dalam penggunaan go payuntuk keperluan transaksi pribadi

Terdapat risiko yang besar dalam penggunaan go pay untuk keperluan transaksi pribadi

Keputusan menggunakan go pay untuk keperluan transaksi pribadi menggunakan adalah keputusan yang berisiko

Saya merasa familiar dengan go pay

Saya merasa familiar untuk melakukan pembayaran transaksi pribadi dengan menggunakan go pay

5. Trust (Gefen 2000; Secara keseluruhan, penggunaan go pay dapat dipercaya

Jarvenpaa et al.

2000)

Go pay menginginkan agar dikenal sebagai salah satu penyedia dompet elektronik yang menjaga komitmen dan kepercayaan

Saya percaya bahwa go pay berupaya menjaga selalu kepentingan saya dalam bertransaksi

Meskipun saya tidak dapat memantau, saya percaya bahwa go payakan melakukan tugas dengan semestinya 


\begin{tabular}{cll}
\hline No. & Laten variabel & Indikator/item pertanyaan \\
\hline 6. & $\begin{array}{l}\text { Satisfaction (Pavlou } \\
\text { 2003; Spreng et al. } \\
\text { 1997) }\end{array}$ & $\begin{array}{l}\text { Secara umum, saya merasa puas dengan pengalaman transaksi di masa lalu selama } \\
\text { menggunakan go pay } \\
\text { Saya merasa frustasi mengenai pengalaman saya selama menggunakan go pay } \\
\text { Secara keseluruhan, saya merasa puas dengan go pay }\end{array}$ \\
7. & $\begin{array}{l}\text { Reputation (Pavlou } \\
\text { 2003) }\end{array}$ & $\begin{array}{l}\text { Saya merasa tidak puas dengan layanan yang diberikan oleh go pay di masa lalu } \\
\text { Go pay memiliki renatasi dang baik di antara para penyedia jasa sejenis } \\
\text { Go pay memiliki reputasi sebagai electronik wallet yang dapat diandalkan } \\
\text { Go pay memiliki reputasi yang buruk sebagai penyedia jasa dompet elektronik }\end{array}$ \\
8. & $\begin{array}{l}\text { Familiarity (Gefen } \\
\text { 2000) }\end{array}$ & Saya merasa cukup familiar dengan penggunaan go pay untuk transaksi pribadi \\
\hline
\end{tabular}

\section{Pengujian Instrumen Penelitian}

Uji Non-respons Bias. Uji non-respons bias dilakukan untuk mengindetifikasi apakah terdapat perbedaan karakteristik antara subyek yang berpartisipasi dalam penelitian dan yang tidak bersedia untuk berpartisipasi dalam penelitian. Karena penelitian ini tidak menggunakan data sekunder, maka untuk melakukan pengujian non-response bias digunakan proksi responden yang mengembalikan kuesioner lebih awal dan responden yang mengembalikan kuesioner lebih akhir. Keseluruhan responden dibagi menjadi dua, yaitu responden yang mengembalikan kuesioner pada rentang waktu yang lebih awal dengan rentang waktu yang lebih akhir. Responden yang mengembalikan lebih awal dijadikan proksi sebagai responden yang benar-benar berpartisipasi dalam penelitian ini sedangkan responden yang mengembalikan lebih akhir dijadikan sebagai representasi dari populasi yang tidak bersedia mengembalikan kuesioner. Pengujian dilakukan dengan uji t terhadap item-itempertanyaan dalam kuesioner (Cooper dan Schindler 2013). Apabila uji t menunjukkan tidak ada perbedaan yang signifikan secara statistik diantara item-item pertanyaan dalam kuesioner, maka tidak terdapat non response bias dalam penelitian ini atau data sampel memiliki kesamaan respon.

Uji Model. Suatu konsep dan model penelitian tidak dapat diuji dalam suatu model untuk memprediksi hubungan relasional dan kausal jika belum melewati tahap pengujian model. Model pengukuran sendiri digunakan untuk menguji validitas konstruk dan reliabilitas instrumen. Uji validitas dilakukan untuk mengetahui kemampuan instrumen penelitian untuk mengukur apa yang seharusnya diukur (Hair et al. 2013). Uji reliabilitas digunakan untuk mengukur konsistensi alat ukur dalam mengukur suatu konsep atau dapat juga digunakan untuk mengukur konsistensi responden dalam menjawab pertanyaan dalam kuesioner atau instrument penelitian.

Uji Validitas. Validitas terdiri dari validitas eksternal dan validitas internal. Validitas eksternal menunjukkan seberapa jauh hasil suatu penelitian adalah valid yang dapat digeneralisir ke semua objek, situasi dan waktu yang berbeda. Validitas internal menunjukkan kemampuan dari instrumen penelitian untuk mengukur apa yang seharusnya diukur dari suatu konsep (Sekaran \& Bougie 2013).

Validitas konstruk. Validitas konstruk menunjukkan seberapa baik hasil penelitian yang diperoleh dari penggunaan suatu pengukuran sesuai teori-teori yang digunakan untuk mendefinisikan suatu konstruk (Hair et al. 2013). Korelasi yang kuat antara konstruk dan item-item pertanyaannya dan hubungan yang lemah dengan variabel lainnya merupakan salah satu cara untuk menguji validitas konstruk (construct validity). Validitas konstruk terdiri dari validitas konvergen dan validitas diskriminan.

Validitas konvergen. Validitas konvergen berhubungan dengan prinsip bahwa pengukur-pengukur dari suatu konstruk seharusnya berkorelasi tinggi. Validitas konvergen terjadi jika skor yang 
diperoleh dari dua instrumen yang berbeda untuk mengukur konstruk yang sama mempunyai korelasi yang tinggi. Korelasi yang tinggi antar item-item yang digunakan untuk mengukur konsep tersebut menunjukkan bahwa item-item tersebut mengkerucut ke dalam suatu konsep tunggal (Hair et al. 2013).

Dalam metode PLS, uji validitas konvergen dengan indikator reflektiff dinilai berdasarkan pada loading factor. Loading factor adalah angka yang menunjukkan korelasi antara skor suatu item pertanyaan dengan skor konstruk indikator-indikator yang mengukur konstruk tersebut. Hair et al. (2013) mengemukakan bahwa rule of thumb yang biasanya digunakan untuk membuat pemeriksaan awal matrik faktor adalah $+0,30$ dipertimbangkan telah memenuhi level minimal, untuk loading faktor $\pm 0,40$ dianggap lebih baik, dan untuk loading faktor $>0.50$ dianggap signifikan secara praktis. Dengan demikian, semakin tinggi nilai loading factor, maka semakin penting peranan loading dalam menginterpretasi matrik faktor. Rule of thumb yang digunakan untuk validitas konvergen adalah outer loading $>0,7$, communality $>0,5$ dan average variance extracted (AVE) $>0,5$ (Hair et al. 2013).

Validitas diskriminan. Validitas diskriminan berhubungan dengan prinsip bahwa pengukur-pengukur konstruk yang berbeda seharusnya tidak berkorelasi dengan tinggi. Validitas diskriminan terjadi jika dua instrumen yang berbeda yang mengukur dua konstruk yang diprediksi tidak berkorelasi menghasilkan skor yang memang tidak berkorelasi (Cooper \& Schindler 2013).

Tabel 2. Parameter uji validitas dalam model pengukuran PLS

\begin{tabular}{lll}
\hline Uji validitas & Parameter & Rule of thumbs \\
\hline Konvergen & Loading factor & Lebih dari 0,7 \\
& Average variance extracted $(A V E)$ & Lebih dari 0,5 \\
& Communality & Lebih dari 0,5 \\
Diskriminan & Akar AVE dan korelasi variabel laten & Akar AVE > korelasi variabel laten \\
& Cross loading & Lebih dari 0,7 dalam satu variabel \\
\hline
\end{tabular}

Uji validitas diskriman dapat dilakukan dengan menggunakan cross loading pengukuran dengan konstruknya. Metode lain yang digunakan untuk menilai validitas diskriminan adalah dengan membandingkan akar AVE untuk setiap konstruk dengan korelasi antara konstruk dengan konstruk lainnya dalam model. Suatu model mempunyai validitas diskriminan yang cukup jika akar AVE untuk setiap konstruk lebih besar dari pada korelasi antara konstruk dengan konstruk lainnya dalam model (Hair et al. 2013). Secara ringkas, parameter yang digunakan untuk uji validitas dalam model pengukuran PLS disajikan dalam Tabel 2.

Uji Reliabilitas. Selain uji validitas, PLS juga perlu melakukan uji reliabilitas untuk mengukur konsistensi internal alat ukur. Reliabilitas menunjukkan akurasi, konsistensi, dan ketepatan suatu alat ukur dalam melakukan pengukuran. Uji reliabilitas dalam PLS dapat menggunakan dua metode, yaitu Cronbach's alpha dan Composite reliability(Hair et al. 2013).

Cronbach's alpha mengukur batas bawah nilai reliabilitas suatu konstruk sedangkan composite reliability mengukur nilai sesungguhnya reliabilitas suatu konstruk. Namun, composite reliability dinilai lebih baik dalam mengestimasi konsistensi internal suatu konstruk (Salisbury et al. 2002).

Rule of thumb nilai Cronbach alpha atau composite reliability harus lebih besar dari 0,7 meskipun 0,6 masih dapat diterima (Hair et al. 2013). Namun sesunggguhnya uji konsistensi internal tidak mutlak dilakukan jika validitas konstruk telah terpenuhi. Hal ini karena konstruk yang valid adalah konstruk yang reliabel, sebaliknya konstruk yang reliabel belum tentu valid (Cooper \& Schindler 2013). 
Model Struktural (Inner Model). Model struktural dalam 70 PLS dievaluasi dengan menggunakan $\mathrm{R}^{2}$ untuk konstruk dependen, dan nilai koefisien path atau $t$-values tiap path untuk uji signifikansi antar konstruk dalam model struktural. Nilai $\mathrm{R}^{2}$ digunakan untuk mengukur tingkat variasi perubahan variabel independen terhadap variabel dependen. Semakin tinggi nilai $\mathrm{R}^{2}$ berarti semakin baik model prediksi dari model penelitian yang diajukan. Sebagai contoh, jika $\mathrm{R}^{2}$ sebesar 0,7 , maka nilai berarti bahwa variasi perubahan variabel dependen yang dapat dijelaskan oleh variabel independen adalah sebesar 70 persen, sedangkan sisanya dijelaskan oleh variabellain yang tidak dispesifikasikan dalam model penelitian. Namun, $\mathrm{R}^{2}$ bukanlah parameter absolut ketepatan model prediksi karena dasar hubungan teoritis adalah parameter yang paling utama untuk menjelaskan hubungan kausalitas tersebut.

Nilai koefisien path atau inner model menunjukkan tingkat signifikansi dalam pengujian hipotesis. Skor koefisien path atau inner model yang ditunjukkan oleh nilai $T$-statistics, harus di atas 1,96 untuk hipotesis dua sisi (two-tailed) dan di atas 1,64 untuk hipotesis yang diuji dengan satu sisi (one-tailed). Kedua nilai tersebut digunakan pada tingkat alpha 5 persen dan power 80 persen (Hair et al. 2013).

Spesifikasi Model PLS. Spesifikasi model penelitian yang menggunakan PLS untuk analisis jalur (path analysis) terdiri dari tiga jenis, yaitu inner model, outer model, dan weight regression. Inner model menunjukkan spesifikasi hubungan kausal antar variabel laten (model structural). Outer model menunjukkan spesifikasi hubungan antara variabel indikator atau parameter yang diestimasi dengan variabel latennya. Weight relation menunjukkan hubungan nilai varian antar indicator dengan variabel latennya sehingga diasumsikan memiliki variabel mean sama dengan nol dan varian sama dengan satu untuk menghilangkan konstanta dalam persamaan kausalitas (Hair et al. 2013).

\section{AnalisisData}

Penelitian ini menggunakan structural equation modelling (SEM) untuk menguji model struktural yang dikembangkan berdasarkan kajian literatur. Pendekatan partial least square (PLS) digunakan untuk melalukan penilaian terhadap instrumen pengukuran yang digunakan. Dengan menggunakan alat yang sama, yaitu PLS, penelitian ini menguji hipotesis yang diajukan di bab sebelumnya.

Hingga saat ini, masih terdapat perdebatan mengenai keunggulan dan kelemahan penggunaan alat-alat untuk SEM. Misalnya Goodhue et al. (2012), menemukan bahwa PLS tidak memberikan hasil lebih buruk dibandingkan dengan LISREL dalam hal kemampuan untuk melakukan analisis statistik dan menghindari kesalahan positif. Untuk penelitian ini, pendekatan PLS dipilih karena dengan pertimbangan bahwa metode ini lebih sesuai untuk penelitian yang masih dalam tahap awal pengembangan model penelitian. Penelitian ini cenderung mengidentifikasi konstruk yang berpengaruh terhadap kepercayaan (trust), dan bukannya berupaya untuk mengkonfirmasi model penelitian yang telah benar-benar terbentuk dengan stabil (Goodhue et al. 2012; Hair et al. 2013). Untuk melalukan evaluasi terhadap model yang dikembangkan, penelitian ini menggunakan software SmartPLS yang dapat diperoleh secara gratis dan legal. Untuk memvalidasi, penelitian ini mengikuti saran yang dikemukakan oleh Straub et al. (2004). Metode yang digunakan tersebut sesuai untuk penelitian yang mengadopsi paradigma positivist.

Data deskriptif responden. Untuk menguji model penelitian yang dikembangkan dalam penelitian ini, peneliti mengembangkan kuesioner yang kemudian didistribusikan kepada sampel. Sample dalam penelitian ini adalah mahasiswa. Sejumlah 222 berpartisipasi dalam penelitian ini. Setelah melakukan screening awal, terdapat sejumlah 7 kuesioner yang tidak terisi lengkap sehingga tidak diikutkan dalam analisis lebih lanjut dan menyisakan 215 kuesioner.

Penggunaan mahasiswa sebagai sampel penelitian seringkali mendapatkan kritikan. Akan tetapi, peneliti berpendapat penggunaan mahasiswa sebagai sampel dalam penelitian ini adalah tepat dengan dua alasan. Pertama, mahasiswa tergolong dalam usia muda yang berkisar antara 17- 
25 tahun. Usia-usia tersebut tergolong muda dan memiliki kecenderungan lebih tinggi untuk mengadopsi inovasi dibandingkan usia yang lebih tinggi. Kedua, mahasiswa memiliki pengetahuan yang cukup baik terhadap teknologi dibandingkan dengan masyarakat secara umum. Dapat dikatakan semua mahasiswa minimal pernah mengoperasikan smartphone.

Tabel 3. Profil deskriptif responden

\begin{tabular}{|c|c|c|c|c|c|c|}
\hline \multirow{2}{*}{\multicolumn{2}{|c|}{ 1. Jenis kelamin }} & \multicolumn{3}{|c|}{ Laki-laki } & \multicolumn{2}{|c|}{ Perempuan } \\
\hline & & \multicolumn{3}{|c|}{$171(67 \%)$} & \multicolumn{2}{|c|}{$44(33 \%)$} \\
\hline \multirow{2}{*}{2.} & \multirow{2}{*}{ Usia } & 18-24 tahun & \multicolumn{2}{|c|}{ 25-34 tahun } & 35-44 tahun & 45-54 tahun \\
\hline & & $215(100 \%)$ & & 0 & 0 & 0 \\
\hline \multirow{2}{*}{3.} & \multirow{2}{*}{ Pendidikan } & SLTA & \multicolumn{2}{|c|}{ Diploma } & Sarjana & Lain-lain \\
\hline & & $215(100 \%)$ & \multicolumn{2}{|r|}{0} & 0 & 0 \\
\hline \multirow{2}{*}{4.} & \multirow{2}{*}{$\begin{array}{l}\text { Pengetahuan tentang } \\
\text { teknologi mobile phone }\end{array}$} & Rendah & \multicolumn{2}{|c|}{ Menengah } & Tinggi & Sangat tinggi \\
\hline & & 0 & \multicolumn{2}{|r|}{0} & $159(74 \%)$ & $56(1 \%)$ \\
\hline \multirow{2}{*}{5.} & \multirow{2}{*}{$\begin{array}{l}\text { Nilai transaksi yang } \\
\text { pernah dilakukan }\end{array}$} & $<20.000$ & \multirow{2}{*}{\multicolumn{2}{|c|}{$\begin{array}{c}20.000-50.000 \\
58(26 \%)\end{array}$}} & $50.000-100.000$ & $100.000-500.000$ \\
\hline & & $133(61 \%)$ & & & $24(7,4 \%)$ & 0 \\
\hline \multirow{2}{*}{6.} & \multirow{2}{*}{$\begin{array}{l}\text { Durasi pengalaman } \\
\text { menggunakan Go Pay }\end{array}$} & $<3$ bulan & \multicolumn{2}{|c|}{ 3-6 bulan } & 6-12 bulan & $>12$ bulan \\
\hline & & $11(6 \%)$ & \multicolumn{2}{|c|}{$44(20 \%)$} & $160(74 \%)$ & 0 \\
\hline \multirow{2}{*}{7.} & \multirow{2}{*}{$\begin{array}{l}\text { Jenis mobile phone } \\
\text { yang digunakan }\end{array}$} & Blackberry & \multicolumn{2}{|c|}{ Android } & Apple & Lainnya \\
\hline & & 0 & \multicolumn{2}{|c|}{$202(94 \%)$} & $13(6 \%)$ & 0 \\
\hline & \multirow{2}{*}{$\begin{array}{l}\text { Jumlah pengeluaran } \\
\text { konsumsi per bulan }\end{array}$} & $<1$ juta & \multicolumn{2}{|c|}{1 juta -1.5 juta } & $\begin{array}{l}1.5 \text { juta }-2 \\
\text { juta }\end{array}$ & $>2.5$ juta \\
\hline & & $54(25 \%)$ & \multicolumn{2}{|c|}{$87(40 \%)$} & $64(30 \%)$ & $10(5 \%)$ \\
\hline \multirow[t]{2}{*}{9.} & \multirow{2}{*}{$\begin{array}{l}\text { Tujuan penggunaan Go } \\
\text { Pay }\end{array}$} & $\begin{array}{l}\text { Untuk mempe } \\
\text { transaksi deng }\end{array}$ & \multicolumn{3}{|c|}{$\begin{array}{l}\text { h } \\
\text { ek } \\
\text { transaksi dengan pihak lain }\end{array}$} & Keduanya \\
\hline & & \multicolumn{2}{|c|}{175 (81\%) } & \multicolumn{2}{|r|}{$35(16 \%)$} & $5(3 \%)$ \\
\hline
\end{tabular}

\section{Uji kelayakan model}

Uji Validitas. Tahap pertama penilaian dilakukan dengan cara menganalisis item reliability dan convergent validity dari masing-masing konstruk. Untuk mencapai tujuan ini, maka peneliti menganalisis factor loading dari masing-masing item secara individual dari konstruk yang dibentuk melalui revieu literatur. Analisis lainnya yang dilakukan pada tahap ini adalah average variance extracted (AVE).

Dari hasil analisis diperoleh bahwa seluruh loading factor bernilai signifikan pada taraf uji 0.01, dan juga bernilai di atas nilai minimum yang disyaratkan yaitu 0,707 . Selain itu, nilai AVE dari masing-masing konstruk juga di atas nilai minimum yang disyaratkan yaitu 0,50 yang menunjukan bahwa variabel laten dari konstruk mampu menjelaskan minimum $50 \%$ dari varians yang ada dalam suatu item. Dengan melihat hasil nilai berbagai uji ini, maka dapat dikatakan bahwa instrumen yang digunakan dalam penelitian ini telah memiliki adequate degree of validity (Chin 1998).

Tahap kedua, peneliti melakukan penilaian terhadap discriminant validity dari konstruk. Penilaian ini dilakukan dengan membandingkan antara squre of root dari AVE dari masing-masing konstruk dengan korelasi antar konstruk yang lain. Hasil analisis menunjukkan bahwa model yang dikembangkan dalam penelitian ini memiliki discriminant validity yang memadai. Akar dari AVE masing-masing konstruk bernilai lebih besar dari pada korelasi antar konstruk (Fornell \& Larcker 1981).

Berdasarkan pada rekomendasi yang dikemukakan oleh Gefen dan Straub (2005), peneliti juga melakukan analisis terhadap cross loading diantara masing-masing item. Hasil uji menunjukkan 
bahwa masing-masing item memiliki loading lebih tinggi dari 0,71 untuk membentuk konstruk yang diharapkan dan bernilai 0,1 lebih rendah di konstruk yang lain. Nilai loading yang tinggi untuk membentuk konstruk yang diharapkan dan bernilai rendah untuk konstruk yang memang tidak menjadi target ini menunjukkan bahwa instrumen penelitian ini memiliki convergent validity dan discriminant validity.

Seperti disebutkan di bagian sebelumnya, uji convergent validity dilakukan dengan melakukan analisis terhadap cross loading antara indikator dengan konstruk atau variabel laten. Berdasarkan hasil analisis diperoleh bahwa seluruh item-item pertanyaan yang digunakan dalam penelitian ini memenuhi syarat minimum convergent validity. Dengan kata lain, seluruh indikator yang digunakan memiliki nilai minimum 0,7. Jika ternyata terdapat indikator yang menghasilkan nilai lebih kecil dari 0,7 , maka peneliti tidak dapat melanjutkan analisisnya untuk melakukan uji hipotesis. Alternatif yang dapat ditempuh adalah menghapuskan indikator tersebut dan tidak diikutkan dalam uji lebih lanjut. Akan tetapi, karena seluruh indikator yang digunakan telah memenuhi syarat minimum, maka analisis selanjutnya dapat dilakukan.

Tabel 4. Cross loading antara indikator dengan konstruk

\begin{tabular}{lrrrrrrrr}
\hline & EOU & \multicolumn{1}{c}{ FAM } & \multicolumn{1}{c}{ ITU } & \multicolumn{1}{l}{ POU } & \multicolumn{1}{c}{ REP } & \multicolumn{1}{c}{ RIS } & \multicolumn{1}{l}{ SAT } & \multicolumn{1}{c}{ TRS } \\
\hline EOU1 & 0.854 & 0.001 & 0.095 & 0.024 & 0.081 & 0.092 & -0.118 & -0.023 \\
EOU2 & 0.913 & -0.054 & 0.114 & 0.072 & -0.023 & 0.073 & -0.059 & 0.018 \\
EOU3 & 0.758 & 0.053 & 0.06 & 0.023 & -0.023 & 0.054 & -0.134 & 0.019 \\
FAM1 & -0.035 & 0.858 & -0.073 & -0.071 & -0.032 & 0.077 & -0.039 & 0.081 \\
FAM2 & 0.018 & 0.826 & -0.109 & -0.005 & -0.055 & 0.009 & -0.014 & 0.056 \\
FAM3 & -0.012 & 0.774 & -0.069 & -0.066 & 0.025 & -0.093 & -0.104 & 0.054 \\
ITU1 & 0.072 & -0.017 & 0.735 & 0.031 & -0.05 & 0.029 & 0.038 & -0.16 \\
ITU2 & 0.088 & -0.018 & 0.771 & 0.144 & -0.085 & 0.069 & 0.064 & -0.069 \\
ITU3 & 0.105 & -0.159 & 0.878 & 0.161 & 0.05 & 0.125 & 0.004 & -0.142 \\
POU1 & -0.014 & -0.056 & 0.069 & 0.698 & -0.003 & 0.05 & 0.012 & 0.066 \\
POU2 & 0.029 & 0.004 & 0.114 & 0.787 & 0.033 & -0.012 & -0.016 & 0.149 \\
POU3 & 0.098 & -0.053 & 0.143 & 0.718 & -0.055 & 0.085 & 0.016 & -0.021 \\
POU4 & 0.02 & -0.13 & 0.091 & 0.668 & 0.044 & 0.021 & -0.007 & 0.004 \\
REP1 & -0.022 & -0.053 & -0.01 & -0.02 & 0.936 & 0.055 & -0.074 & -0.096 \\
REP2 & 0.036 & -0.015 & 0.003 & 0.007 & 0.925 & 0.066 & -0.081 & -0.076 \\
REP3 & 0.048 & 0.053 & -0.097 & 0.063 & 0.577 & -0.041 & -0.026 & -0.033 \\
REP4 & 0.038 & 0.051 & -0.057 & -0.002 & 0.553 & -0.08 & -0.054 & 0.003 \\
RIS1 & 0.029 & 0.01 & 0.043 & -0.01 & 0.043 & 0.791 & -0.071 & 0.008 \\
RIS2 & 0.108 & 0.013 & 0.108 & 0.064 & 0.045 & 0.969 & -0.058 & -0.008 \\
RIS3 & 0.109 & 0.017 & -0.011 & 0.043 & -0.011 & 0.462 & -0.033 & 0.028 \\
SAT1 & -0.091 & -0.084 & 0.051 & -0.023 & -0.095 & -0.081 & 0.915 & 0.088 \\
SAT2 & -0.113 & 0.076 & -0.051 & 0.051 & -0.084 & -0.03 & 0.663 & 0.023 \\
SAT3 & -0.071 & -0.051 & 0.059 & 0.055 & -0.005 & -0.011 & 0.773 & 0.038 \\
SAT4 & -0.071 & -0.044 & -0.004 & -0.052 & -0.019 & -0.042 & 0.61 & 0.025 \\
TRS1 & 0.002 & 0.077 & -0.158 & 0.016 & -0.094 & -0.038 & -0.033 & 0.802 \\
TRS2 & 0.012 & 0.015 & -0.146 & 0.043 & -0.041 & -0.005 & 0.055 & 0.727 \\
TRS3 & -0.026 & 0.087 & -0.108 & 0.078 & -0.101 & -0.042 & 0.105 & 0.800 \\
TRS4 & 0.045 & 0.057 & -0.046 & 0.117 & -0.021 & 0.092 & 0.094 & 0.678 \\
\hline & & & & & & & & \\
& & & & & & & &
\end{tabular}

Uji Reliabilitas. Tahap berikutnya adalah penilaian terhadap konsistensi internal. Peneliti melakukan penilaian terhadap konsistensi internal dan scale reliability dengan menghitung composite reliability (CR) dan nilai Cronbach alpha. Nilai CR untuk semua konstruk dalam penelitian ini paling kecil bernilai 0,81 sedangkan nilai Cronbach alpha bernilai 0,708. Nilai tersebut menunjukkan bahwa reliabilitas instrumen penelitian ini di atas nilai yang biasanya diterima, yaitu masing-masing bernilai 0,6 dan 0,7 untuk CR dan Cronbach alpha (Bagozzi 2011; Gefen et al. 2000). 
Uji reliabilitas bertujuan untuk menguji sejauh mana konsistensi instrumen yang digunakan dalam penelitian. Pengujian reliabilitas dalam penelitian ini menggunakan koefisien Cronbach alpha dan item to total correlation. Cronbach alpha dapat diterima jika bernilai lebih besar atau sama dengan 0,70 sedangkan item to total correlation minimal harus bernilai 0,50 (Hair et al. 2013; Sekaran, 1992). Skor item to total correlation yang lebih kecil dari 0,50 tetap dapat diterima jika butir-butir yang dieliminasi akan menghasilkan Cronbach alpha yang lebih kecil.

Tabel 5 menyajikan ringkasan hasil penilaian dengan menampilkan hasil average variance extracted, Cronbach alpha, dan composite reliability dari semua konstruk. Dari tabel tersebut dapat dilihat bahwa seluruh nilai Cronbach alpha bernilai di atas 0,70 sehingga dapat dikatakan seluruh kontruk memiliki reliabilitas. Cronbach alpha terkecil ditemukan pada konstruk intention to use dengan nilai sebesar 0,719 sedangkan nilai Cronbach alpha terbesar ditemukan pada konstruk 0,812 untuk konstruk perceived ease of use.

Tabel 5. Cronbach alpha, composite reliability dan averagevariance extracted(AVE)

\begin{tabular}{lcccc}
\hline \multicolumn{1}{c}{ Konstruk } & Cronbach's Alpha & rho_A & $\begin{array}{c}\text { Composite } \\
\text { Reliability }\end{array}$ & $\begin{array}{c}\text { Average Variance } \\
\text { Extracted (AVE) }\end{array}$ \\
\hline EOU & 0.812 & 0.948 & 0.881 & 0.712 \\
FAM & 0.768 & 0.829 & 0.86 & 0.673 \\
ITU & 0.719 & 0.779 & 0.839 & 0.635 \\
POU & 0.708 & 0.735 & 0.81 & 0.517 \\
REP & 0.811 & 0.909 & 0.846 & 0.592 \\
RIS & 0.771 & 0.896 & 0.802 & 0.593 \\
SAT & 0.772 & 1.154 & 0.833 & 0.562 \\
TRS & 0.747 & 0.766 & 0.84 & 0.568 \\
\hline
\end{tabular}

Analisis Varians $\left(\mathrm{R}^{2}\right)$

Nilai estimasi yang diperoleh dari analisis PLS diantaranya adalah standardised coefficient, signifikansi koefisien, dan varians $\left(\mathrm{R}^{2}\right)$ disajikan di Tabel 6. Berdasarkan nilai $\mathrm{R}^{2}$, dapat diketahui bahwa model yang dikembangkan dalam penelitian ini mampu menjelaskan $692 \%$ varians dari intentions to use, $25,1 \%$ dari varians perceived usefulness, $38,7 \%$ varians perceived ease of use, $34,9 \%$ varians perceived risk, dan $27 \%$ varians trust.

Tabel 6. Nilai $\mathrm{R}^{2}$ untuk masing-masing konstruk

\begin{tabular}{lc}
\hline Konstruk & R Square \\
\hline EOU & 0.387 \\
ITU & 0.692 \\
POU & 0.251 \\
RIS & 0.349 \\
TRS & 0.270 \\
\hline
\end{tabular}

\section{Pengujian Hipotesis dan Diskusi}

Seperti telah dijelaskan di bagian sebelumnya, model struktural yang dikembangkan dalam penelitian ini diuji dengan menggunakan PLS. Untuk menguji signifikansi loading factor dan koefisien, peneliti menggunakan bootstrapping technique sehingga jumlah sampel yang awalnya berjumlah 215 menggandakan dengan sendirinya sehingga berjumlah 1.000.

Tabel 6 di atas menyajikan hasil uji hipotesis penelitian yang diajukan dalam penelitian ini. Secara ringkas, hasil pengujian tersebut dijelaskan di bagian berikut ini dan kemudian akan didiskusikan di bagian berikutnya. 
Tabel 7. Hasil uji hipotesis penelitian

\begin{tabular}{llcccccc}
\hline & Hipotesis & $\begin{array}{c}\text { Original } \\
\text { Sample (O) }\end{array}$ & $\begin{array}{c}\text { Sample } \\
\text { Mean (M) }\end{array}$ & $\begin{array}{c}\text { Stand. Dev. } \\
\text { (STDEV) }\end{array}$ & $\begin{array}{c}\text { T Statistics } \\
(\text { (O/STDEVI) }\end{array}$ & $\begin{array}{c}\text { P } \\
\text { Values }\end{array}$ & Hasil \\
\hline H1 & POU $\rightarrow$ ITU & 0.155 & 0.159 & 0.094 & 1.658 & 0.098 & diterima \\
H2 & EOU $\rightarrow$ ITU & 0.098 & 0.098 & 0.081 & 1.201 & 0.23 & diterima \\
H3 & EOU $\rightarrow$ POU & 0.054 & 0.053 & 0.106 & 0.513 & 0.608 & diterima \\
H4 & RIS $\rightarrow$ ITU & 0.087 & 0.054 & 0.112 & 0.776 & 0.438 & diterima \\
H5 & TRS $\rightarrow$ ITU & -0.167 & -0.172 & 0.078 & 2.146 & 0.032 & diterima \\
H6 & TRS $\rightarrow$ RIS & -0.006 & 0.011 & 0.104 & 0.06 & 0.952 & diterima \\
H7 & TRS $\rightarrow$ POU & 0.082 & 0.075 & 0.134 & 0.608 & 0.543 & diterima \\
H8 & EOU $\rightarrow$ TRS & 0.017 & 0.014 & 0.087 & 0.19 & 0.849 & diterima \\
H9 & SAT $\rightarrow$ TRS & 0.074 & 0.082 & 0.125 & 0.595 & 0.552 & diterima \\
H10 & REP $\rightarrow$ TRS & -0.083 & -0.084 & 0.111 & 0.745 & 0.456 & diterima \\
H11 & FAM $\rightarrow$ TRS & 0.084 & 0.088 & 0.092 & 0.912 & 0.362 & diterima \\
H12 & FAM $\rightarrow$ EOU & -0.018 & 0.003 & 0.113 & 0.159 & 0.874 & diterima \\
\hline
\end{tabular}

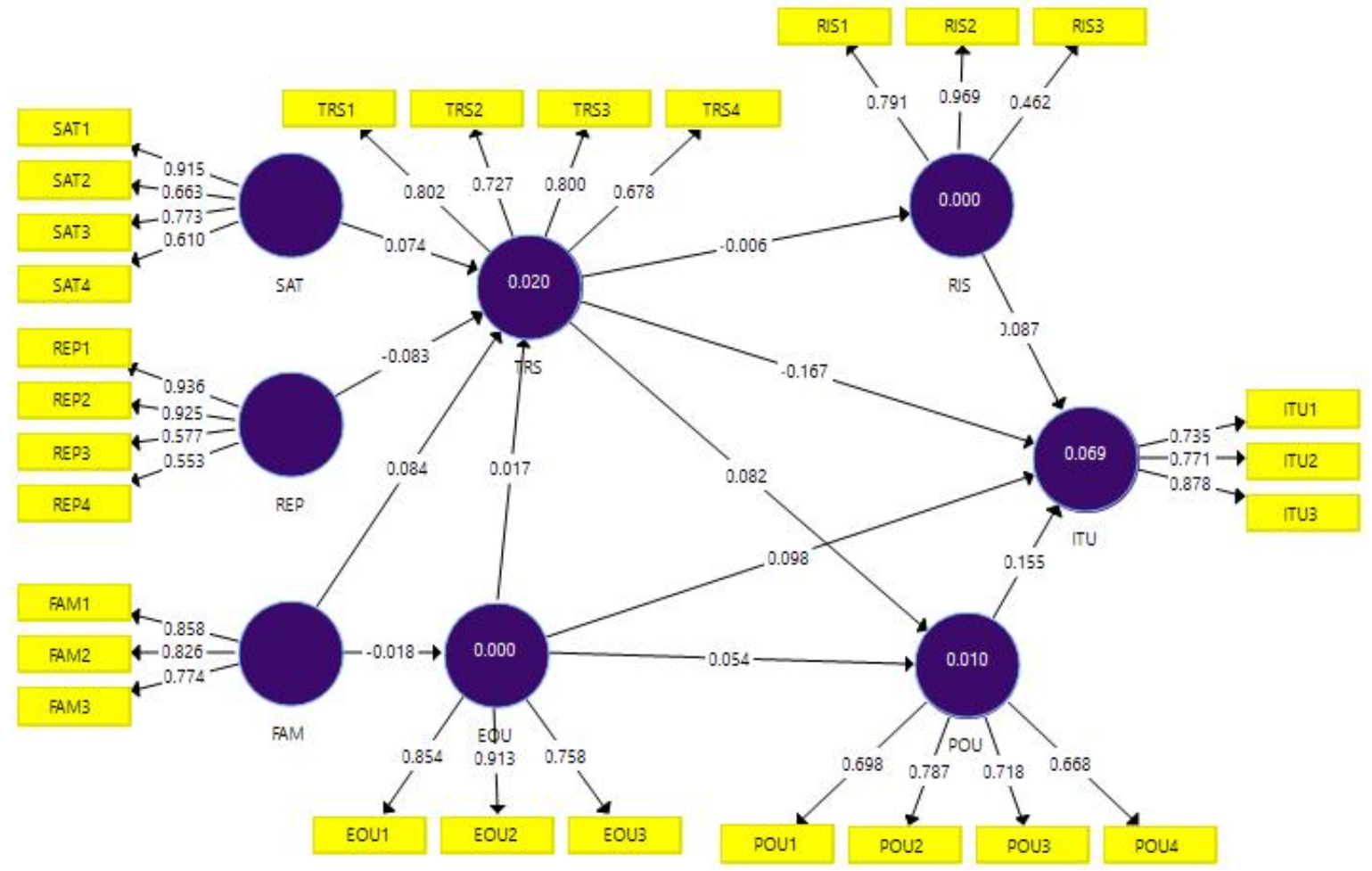

Gambar 1. Hasil uji analisis model

Penelitian ini menguji secara empiris intention untuk menggunakan layanan dompet elektronik yang ditawarkan oleh Go Pay. Pengujian dilakukan dengan menggunakan model dasar TAM yang dimodikasi dengan menggunakan beberapa variabel laten tambahan. Peneliti memfokuskan pada faktor-faktor yang mempengaruhi trust pelanggan terhadap penggunaan dompet elektronik. Trust ini secara tidak langsung berpengaruh terhadap intention melalui perceived usefulness dan perceived risk.

Secara umum, penelitian ini menemukan bahwa terdapat dukungan terhadap hipotesis yang diajukan dalam penelitian ini. Pertama, data penelitian ini menunjukkan bahwa intention to use dalam menggunakan dompet elektronik dipengaruhi oleh risk dan perceived usefulness. Penelitin ini menemukan bahwa perceived usefullness memiliki pengaruh yang paling kuat terhadap intention to use. Temuan ini secara tidak langsung memperkuat penelitian-penelitian sebelumnya yang diantaranya dilakukan oleh Gefen dan Straub (2000). Hasil penelitian ini menunjukkan bahwa dompet elek- 
tronik yang ditawarkan oleh Go Pay dipandang bermanfaat bagi para penggunanya. Analisis terhadap efek mediasi menunjukkan bahwa trust memiliki pengaruh tidak langsung terhadap intention to use melalui perceived risk dan perceived usefulness. Oleh karenanya, trust menjadi komponen penting dalam penggunaan dompet elektronik sebagai alat pembayaran elektronik.

Temuan penelitian ini memberikan dukungan terhadap penelitian sebelumnya yang menyatakan bahwa perlunya trust terhadap penyedia jasa dompet elektronik. Selain itu, hasil penelitian ini juga mendukung meta-analysis yang dilakukan oleh Burda dan Teuteberg (2013) yang menyatakan bahwa teknologi digital memandang trust sebagai salah satu element penting. Selain itu, peneliti lain yang melakukan penelitian dengan hasil yang relevan adalah Pavlou (2003) dan Benlian dan Hess (2011). Penelitian-penelitian mereka menemukan bahwa perceived risk berpengaruh negatif terhadap intention to use.

Namun demikian, satu hal yang perlu mendapatkan perhatian adalah perlu kehati-hatian dalam menginterpretasikan temuan ini. Hal ini disebabkan rendahnya nilai koefisien jalur dan rendahnya nilai varians perceived risk. Nilai path coefficient sebesar 0,087 untuk $p<0,01$ sedangkan nilai $\mathrm{R}^{2}$ sebesar 0.069. Salah satu penjelasan terhadap temuan ini adalah kemungkinan disebabkan oleh rendahnya nilai Cronbach alpha konstruk atau variabel laten risk. Nilai Cronbach alpha dari variabel laten risk sebesar 0,771 .

Penelitian sebelumnya menyatakan bahwa risk (risiko) adalah konstruk kompoleks yang bersifat multidimensi sehingga sulit untuk dilakukan pengukuran. Weber et al. (2002) memberikan dukungan empiris dengan menyatakan bahwa risiko dipengaruhi oleh berbagai konteks seperti perbedaan negara, budaya, dan perbedaan domain yang spesifik (domain specific differences). Perbedaan domain yang spesifik ini diantaranya adalah perbedaan jenis teknologi, nilai moneter dari teknologi yang digunakan, dan reputasi komunitas yang menggunakan teknologi tersebut.

\section{Simpulan}

Penelitian ini menganalisis apakah teknologi Go Pay diterima oleh masyarakat, terutama oleh para early adopters of innovation yang dalam penelitian ini diproksi dengan mahasiswa. Mahassiwa adalah kelompok usia yang relatif muda sehingga cenderung memiliki tingkat penerimaan yang tinggi terhadap risiko dari inovasi baru. Disamping itu, mereka juga dipandang lebih familiar dengan teknologi baru. Atas dasar itulah mereka dipilih menjadi sampel penelitian.

Model yang digunakan dalam penelitian ini adalah technology acceptance model yang banyak digunakan untuk analisis penerimaan inovasi teknologi. Model yang digunakan adalah technology acceptance model yang dirumuskan oleh Davis (1989) dan kemudian dimodifikasi dengan memasukkan variabel-variabel laten yang relevan dengan konteks penelitian. Variabelvariabel laten baru yang digunakan dalam penelitian ini adalah familiarity, risk, dan satisfaction. Ketiga variabel laten tersebut tidak ada dalam technology acceptance mode/yang masih asli.

\section{Keterbatasan dan Saran Penelitian Lanjutan}

Penelitian ini hanya menggunakan sampel mahasiswa dari satu fakultas saja, yaitu mahasiswa dari Fakultas Ekonomi UII. Penelitian berikutnya dapat menggunakan sampel mahasiswa yang berasal dari fakultas dan universitas yang berbeda. Secara umum, terdapat keyakinan publik bahwa mahasiswa dari Fakultas Ekonomi memiliki latar belakang ekonomi yang lebih tinggi dibandingkan dengan mahasiswa dari fakultas-fakultas yang lain, misalnya Fakultas Ilmu Agama Islam, Fakultas Matematika dan Ilmu Pengetahuan Alam, dan Fakultas Psikologi dan Ilmu-ilmu Sosial di universitas yang sama. Pandangan publik tersebut juga cukup dapat diterima secara rasional karena memang secara finansial, biaya perkuliahan di fakultas eknonomi lebih tinggi dibandingkan dengan fakultasfakultas yang lain tersebut.

Meskipun keterbatasan penelitian yang hanya menggunakan mahasiswa Fakultas Ekonomi UII sebagai sampel ini juga dapat dikatakan sebagai sebuah kelebihan. Pelanggan yang memiliki 
kemapanan secara ekonomi akan memiliki keberanian lebih tinggi untuk mengadopsi teknologi yang berisiko. Hal ini disebabkan dia masih memiliki kemampuan ekonomi jika adopsi yang dilakukannya memiliki kegagalan. Dengan kata lain, pelanggan dengan latar belakang ekonomi yang mapan lebih risk takers dibandingkan dengan pelanggan yang kurang mapan.

\section{Implikasi Teoritis dan Manajerial}

Penelitian ini memberikan implikasi teoritis dan manajerial. Dari segi teoritis, penelitian ini memberikan implikasi bahwa para manajer harus mempertimbangkan risiko secara lebih cermat bagi para pelanggan yang berusia tua. Hal ini dikarenakan para pelanggan yang berusia lebih cenderung menghindari risiko sedangkan penelitian ini menggunakan responden yang berusia muda. Karenanya, manajer perlu berupaya untuk meminimalkan risiko serendah mungkin. Strategi lain yang perlu dilakukan oleh manajer adalah memberikan edukasi kepada pelanggan berusia tua agar mereka lebih familiar, dan pada akhirnya akan menurunkan persepsi risiko yang muncul dari penggunakan teknologi dompet elektronik.

Model TAM telah banyak digunakan untuk mengamati tingkat penerimaan teknologi baru. Penelitian ini sekali lagi membuktikan bahwa TAM merupakan model yang handal. Hal ini diindikasikah oleh seluruh hipotesis yang dilakukan dalam penelitian ini diterima. Selain itu, penelitian ini juga membuktikan bahwa TAM dapat dilakukan pengembangan dengan menambahkan beberapa variabel lain dan kemudian disematkan ke dalam model yang asli. Variabel-variabel lain yang dapat disematkan ke dalam model TAM untuk penelitian-penelitian berikutnya diantaranya adalah pendidikan, budaya, gaya hidup pengguna teknologi baru.

\section{Daftar Pustaka}

Ackermann, T., Miede, A., Buxmann, P., \& Steinmetz, R. (2011). Taxonomy of technological IT outsourcing risks: Support for risk identification and quantification. Paper presented at the European Conference on Information Systems (ECIS2011), Helsinki, Finland.

Anonim (2006). Aparat Hukum Layak Usut Wajib Pajak Grab, Gojek, dan Uber diretrieve dari http://pitunews.com/aparat-hukum-layak-usut-wajib-pajak-grab-gojek-dan-uber/pada tanggal 11 Mei 2017

Ajzen, I. and Fishbein (1975). Belief, attitude, intention and behavior: An introduction to theory and research.

Bagozzi, R. P. (2011). Measurement and meaning in information systems and organizational research: methodological and philosophical foundations. MIS Quarterly, 35 (2), 261-292.

Benbasat, I., \& Barki, H. (2007). Quovadis TAM? Journal of the Association for Information Systems, 8(4),7.

Benlian, A., \& Hess, T. (2011). Opportunities and risks of software-as-a-service: Findings from a survey of IT executives. Decision Support Systems, 52 (1), 232-246.

Bhattacherjee, A. (2002). Individual trust in on line firms: Scale development and initial test. Journal of Management Information Systems, 19 (1), 211-242.

Burda, D., \& Teuteberg, F. (2013). Sustaining accessibility of information through digital preservation: A literature review. Journal of Information Science, 39 (4), 439-455.

Chin, W. W. (1998). The partial least squares approach to structural equation modeling. InG.A.Marcoulides (Ed.), Modern methods for business research (pp.295-336). Mahwah, NJ, US: Lawrence Erlbaum Associates. 
Chiou,J.-S.,\& Droge,C.(2006). Service quality, trust, specific asset investment, and expertise: Direct and indirect effects inasatisfaction-loyalty framework. Journal of the Academy of Marketing Science, 34 (4), 613-627.

Cho, D.-Y., Kwon, H. J., \& Lee, H.-Y. (2007). Analysis of trust in internet and mobile commerce adoption. Paper presented at the $40^{\text {th }}$ Annual Hawaii International Conference on System Sciences (HICSS2007), Waikoloa, Hawaii.

Cooper, D.R. \& Schindler, P.S., 2013. Business research methods 12th ed., New York, United States: McGraw Hill Education.

Davis, F.D. (1989). Perceived usefulness, perceived ease of use, and user acceptance of information technology. MIS Quarterly, 13 (3), 319-340.

Doney, P. M., \& Cannon, J. P. (1997 Aprill). An examination of the nature of trust in buyer-seller relationships. The Journal of Marketing, 61,35-51.

Flood, D., West, T., and Wheadon, D., 2013. Trends in mobile payments in developing and advanced economies. RBA Bull, 71-80

Fornell, C., \& Larcker, D.F. (1981). Evaluating structural equation models with unobservable variables and measurement error. Journal of Marketing Research, XVII, 39-50

Gefen, D., \& Straub, D. W. (2000). The relative importance of perceived ease of use in IS adoption: A study of e-commerce adoption. Journal of the Association for Information Systems, 1 (8), $1-28$

Gefen, D., Karahanna, E., \& Straub, D. W. (2003). Trust and TAM in online shopping: An integrated model. MIS Quarterly, 27 (1), 51-90.

Gefen, D., Straub, D., \&Boudreau, M. C. (2000). Structural equation modeling and regression: Guidelines for research practice. Communications of the Association for Information Systems, 4(1),7.

Goodhue, D. L., Lewis, W., \& Thompson, R. ( 2012). Does PLS have advantages for small sample size or non-normal data? MIS Quarterly, 36 (3), 891-1001.

Hair, J.F. et al., 2013. Multivariate data analysis 7th ed., Pearson Education Limited.

Hoftstede, G. (1984). Culture's consequences: International differences in work-related values, Sage Publication, London, UK.

Ion, I., Sachdeva ,N., Kumaraguru, P., \& Capkun,S. (2011). Home is safer than the cloud!: Privacy concerns for consumer cloud storage. Paper presented at the7th Symposium on Usable Privacy and Security, Pittsburgh, Pennsylvania.

Jarvenpaa, S. L., Tractinsky, N., \& Vitale, M. (2000). Consumer trust in an internet store. Information Technology and Management, 1 (12), 45-71.

Kim, D. J., Ferrin, D. L., \& Rao, H. R.(2009). Trust and satisfaction, two stepping stones for successful e-commerce relationships: A longitudinal exploration. Information Systems Research, 20 (2), 237-257.

Kim, H.-W., Xu, Y., \& Koh, J. (2004). A comparison of online trust building factors between potential customers and repeat customers. Journal of the Association for Information Systems, 5(10),392-420.

Komiak, S.Y., \& Benbasat, I. (2006). The effects of personalization and familiarity on trust and adoption of recommendation agents. MIS Quarterly, 30 (4),941-960. 
MacKenzie, S. B., Podsakoff, P. M., \& Podsakoff, N. P. (2011). Construct measurement and validation procedures in MIS and behavioral research: Integrating new and existing techniques. MIS Quarterly, 35 (2), 293-334.

Mayer, R. C., Davis, J. H., \& Schoorman, F. D.(1995). An integrative model of organizational trust. Academy of Management Review, 20 (3), 709-734

McAllister, D.J. (1995). Affect-and cognition-based trust as foundations for interpersonal cooperation in organizations. Academy of Management Journal, 38 (1), 24-59.

McKnight, D.H., Cummings, L.L., \& Chervany, N.L. (1998). Initial trust formation in new organizational relationships. Academy of Management Review, 23 (3), 473-490

Pavlou, P. A. (2003). Consumer acceptance of electronic commerce: Integrating trust and risk with the technology acceptance model. International Journal of Electronic Commerce, 7 (3), $101-134$

Pavlou, P. A., Liang, H., \& Xue, Y. (2007). Understanding and mitigating uncertainty in online exchange relationships: A principal-agent perspective. MIS Quarterly, 31 (1), 105-136.

Ross, P.E., 2012. Phone-y money.Spectrum IEEE 49 (6), 60-63.

Rousseau, D. M., Sitkin, S. B., Burt, R. S., \& Camerer, C. (1998). Not so different after all: Acrossdiscipline view of trust. Academy of Management Review, 23 (3), 393-404.

Salisbury, W.D. et al., 2002. Research report: Better theory through measurement-developing a scale to capture consensus on appropriation. Information Systems Research, 13(1), pp.91103.

Sekaran, U. \& Bougie, R., 2013. Research methods for business: A skill-building approach 6th ed., John Wiley \& Sons, Ltd.

Straub, D., Boudreau, M. C., \& Gefen, D. (2004). Validation guidelines for IS positivist research. Communications of the Association for Information Systems, 13 (24), 380-427.

Straub, D., Boudreau, M.C., Gefen, D. (2004). Validation guidelines for IS positivist research, Communications of the Association for Information Systems, 13, 380-427.

Vance, A., Elie-Dit-Cosaque, C., \& Straub, D. W. (2008). Examining trust in information technology artifacts: The effects of system quality and culture. Journal of Management Information Systems, 24 (4), 73-100.

Vander Heijden, H.,Verhagen, T.,\& Creemers, M. (2003). Understanding online purchase intentions: Contributions from technology and trust perspectives. European Journal of Information Systems, 12 (1), 41-48.

Venkatesh, V., \& Bala, H. (2008). Technology acceptance model 3 and a research agenda on interventions. Decision Sciences, 39 (2), 273-315.

Venkatesh, V., \& Davis, F.D. (2000). A theoretical extension of the technology acceptance model: Four longitudinal field studies. Management Science, 46 (2), 186-204.

Wang, W., \& Benbasat, I. (2005). Trust in and adoption of online recommendation agents. Journal of the Association for Information Systems, 6(3),72-101.

Warkentin, M., Gefen, D., Pavlou, P. A., \& Rose, G. M. (2002). Encouraging citizen adoption of egovernment by building trust. Electronic Markets, 12 (3), 157-162.

Weber, E. U., Blais, A. R., \& Betz, N. E. (2002). A domain-specific risk-attitude scale: Measuring risk perceptions and risk behaviors. Journal of Behavioral Decision Making, 15 (4), 263-290. 